\title{
異形鉄筋スタッド方式鋼管矢板基礎頂版結合構造に関する研究

\author{
STUDY ON THE CONNECTED STRUCTURE BETWEEN FOOTING CONCRETE AND \\ STEEL SHEET PIPE PILE WALL BY THE DEFORMED BAR STUD WELDING
}

江見 晋*·古池正宏**.川上圭二***・片山 猛**** By Susumu EMI, Masahiro KOIKE, Keiji KAWAKAMI and Takeshi KATAYAMA

\begin{abstract}
When we try to apply the Horizontal stud welding method with large diameter and long length which we have developed to the connected structure between footing concrete and steel sheet pipe pile wall, we have carried the experimental studies.

Main experimental studies are the mechanical test of stud welding and large scale model test of concrete for steel pipe sheet pile. Large scale model test is the comparison between the new deformed bar stud and some former methods. One of former methods is the connection of shear plate and moment plate, and other is the deformed bar fixed into the concrete in the steel sheet pipe pile. Through these tests we have proved that this connection method has the sufficient shear transfer capacity comparison to the former methods.

While we carried the experimental studies, we have developed the semi-automatic stud welding machine and quality assurance device. Last in this paper, we describe these machine and device briefly.
\end{abstract}

Keywords : stud welding, deformed bar, wall foundation, composite structure

\section{1. まえがき}

鋼管矢板基礎は，橋梁構造物の大型化に伴って河口や 沿岸域に建設される基礎形式として，近年採用が一般化 してきた．昭和 59 年 2 月には, 日本道路協会より「鋼 管矢板基礎設計指針・同解説」'が出版されるとともに, 平成元年に改訂が予定されている「道路橋示方書 IV下部 構造編 (日本道路協会) 」) (以下, “道示”之称す) に も改訂される方向で検討が進められている.

この鋼管矢板基礎の要ともいうべき橋脚との結合部の 構造，すなわち頂版と鋼管矢板との結合構造については (図一1参照), 同上指針において, 通称, プレート・ブ ラケット方式と差し筋方式とが示されている。この 2 方 式はいずれも一長一短があるが，その施工性から最近は 後者の方式が採用され始めている. しかし，プレート・ ブラケット方式は, 現場溶接が主体のためその溶接の信 頼性に問題があり, また差し筋方式は, 鋼管矢板の中詰

* 正会員 阪神高速道路公団工務部次長 ( ₹541 大阪市東区北久太郎町 4-68)

** 正会員阪神高速道路公団大阪第一建設部設計課長補佐 （正559 大阪市住之江区北賀尾町 2-11-8)

*** 正会員 新日本製鉄建材開発技術部部長代理 （宁100 千代田区大手町 2-6-3)

**** 正会員 新日本製鉄建材開発技術部掛長（同上）
めコンクリートの施工管理に結合工の耐力が左右される などの問題がある.これらの技術課題解決のため, 著者 らは，より合理的で施工性向上に寄与する結合形式一ス タッド方式結合一(以下「異形鉄筋スタッド方式頂版結 合工」と称す) を提案する.

すなわち，図一2にみるように，従来のプレートや鉄 筋に代わって，鋼管に現場でスタッドを水平打ちし頂版 と鋼管矢板を一体とするもので，いわば合成析における 鋼析とコンクリート床板との結合構造のイメージであ る.

本報は，異形鉄筋スタッド方式頂版結合工の開発にあ たって実施した頂版結合工の大型模型実験成果ならびに 今回開発した太径・長尺・水平異形鉄筋スタッド溶接方

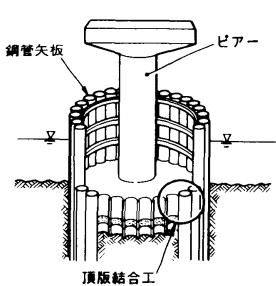

図一1 鋼管矢板基礎摸式図

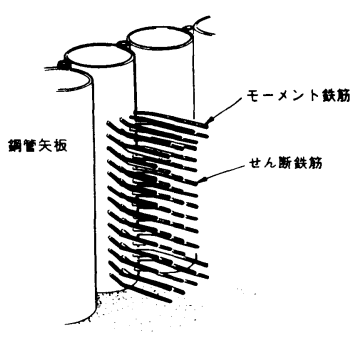

図一2 異形鉄筋スタッド方式 頂版結合工 
法を中心に報告する。

\section{2. 異形鉄筋スタッド方式頂版結合工の検討課題}

\section{（1）設計に関する課題}

鋼管矢板基礎の頂版と鋼管矢板との結合部は，頂版に 作用する荷重を円滑に，かつ安全に鋼管矢板に伝えねば ならない。この結合部に異形鉄筋スタッドを適用する場 合，異形鉄筋スタッド接合により，引張力およびせん断 力を伝達する必要がある．まず，スタッド単体としての 課題であるが，従来スタッド接合における引張耐力の試 験方法については, JASS 6 鉄骨工事改訂案（1981）等 に規定されている. しかし，せん断耐力については，試 験方法の規定がなく, 試験方法そのものを確立する必要 がある.

次に，頂版結合構造においては，スタッドを介在させ た鋼とコンクリートとの合成構造として，引張軸力とせ ん断力の 2 軸応力状態での耐荷力や変形性能を検討し, 設計手法を確立する必要がある。

\section{(2) 施工に関する課題}

異形鉄筋スタッド方式頂版結合工の施工には，太径ス タッドの水平打ちが必要となる。この太径水平打ちの技 術はわが国では未知の分野である.すなわち，差し筋方 式に準じた試算では，この工法の汎用性のため鉄筋は最 小径 $19 \mathrm{~mm} ，$ かつ SD 35 相当の高強度材であることが 必要となった。

施工全体としての課題は,

1) 太径 $(19 \mathrm{~mm})$ かつ高強度異形鉄筋の水平スタッ

ド打設装置の開発

2）スタッド打設装置の自動化

3）品質管理規定值の設定

4）施工管理方法の合理化 等であった。

\section{3. 設計に関する検討一大型模型実験を中心と して一}

\section{（1）実験 概 要}

表一1に実験概要を示す。すなわち，スタッド溶接単 体試験，コンクリートとしての押し抜きせん断試験，さ らに頂版結合構造体としての大型模型実験を行った．特 に大型模型実験としては，せん断力が卓越するモデルで 3 方式（プレート・ブラケット方式，差し筋方式，異形 鉄筋スタッド方式）の比較およびブラケットの効果と偏 心載荷の影響を評価するため合計 5 ケース実施した。

a) スタッド溶接単体試験（A 試験）

スタッドをコンクリートとの合成構造に用いる場合, 異形鉄筋スタッドには引張軸力とせん断力が作用するた め, 引張試験に加えて 2 軸応力状態でのせん断耐力試験
（以下，引張せん断試験と称する）も実施した。スタッ ド径は $19 \mathrm{~mm}$ である. 引張軸力は, サーボ式油圧ポン プにより試験を通じて一定軸力とした。

b）押し抜きせん断耐力試験（B 試験）

頂版に作用する荷重が鋼管矢板（軸力として）に伝達 されるためには，鋼管・スタッド・頂版の 3 者からなる 結合構造の挙動を確認する必要があるため押し抜きせん 断試験を行った。なお，本試験は差し筋方式との比較実 験とした。

試験は鋼管とコンクリートとの接合部にせん断力が作 用するように左右対称構造とした。 またコンクリート内 での鉄筋定着長は鉄筋直径の 30 倍とした。

c) 大型模型実験（C 試験）

異形鉄筋スタッド方式を頂版結合工へ適用するにあ たっての最終試験として実構造物を対象にした従来方式 （プレート・ブラケット方式，差し筋方式）との比較試 験を実施した。

また，橋脚に作用する地震時曲げモーメントは，頂版 を通じて鋼管矢板に偶力として作用すると考えている が，頂版に対称に作用するかどうか，また頂版天端に水 平力が作用することを考え，鉛直中心載荷 $(\mathrm{C}-1)$ のほ か, 偏心モーメントを作用させる実験，すなわちせん断 スパン比を変化させた試験（C-2）を行った.

(1) 使用材質

$\begin{array}{ll}\text { 鋼 } & \text { 管：SKK 41（JIS A 5525） } \\ \text { 異形スタッド : SM 50 A (JIS G 3106) …(表一-2) } \\ \text { 鋼 } \\ \text { 鉄 }\end{array}$

コンクリート：設計基準強度 $240 \mathrm{kgf} / \mathrm{cm}^{2}$ の早強コン クリート (表一3)

(2) 供試体寸法

供武体寸法は, 阪神高速道路公団高速湾岸線 (南伸部) 橋脚をモデルとし，頂版の幾何寸法は約 $1 / 5$ とした。原 設計の設計荷重は，常時杭反力 $R=181.5 \mathrm{tf} /$ 本（鋼管 矢板 $\phi 1000 \mathrm{~mm} \times t 12 \mathrm{~mm})$ であり，このときの各供試

\section{表一2 供試体結合鉄筋の機械的性留}

\begin{tabular}{|c|c|c|c|c|}
\hline 供試 体 & $\begin{array}{l}\text { 鉄䈃 } \\
\text { 呼ひ名 }\end{array}$ & $\begin{array}{l}\text { 隆伏応力 } \\
\left(\mathrm{kgf} / \mathrm{mm}^{2}\right)\end{array}$ & $\begin{array}{l}\text { 破断応力 } \\
\left(\mathrm{kgf} / \mathrm{mm}^{2}\right)\end{array}$ & $\begin{array}{l}\text { 伸び } \\
\text { (\%) }\end{array}$ \\
\hline$A-1 \cdot 2, B-1 \cdot 2$ & D 19 & 35.4 & 53.0 & 23.8 \\
\hline$c-1 \sim c-3$ & D 13 & 36.1 & 54.0 & 24.3 \\
\hline " & D 16 & 36.9 & 51.8 & 28.2 \\
\hline$C-4$ & D 13 & 37.6 & 55. 3 & 26.3 \\
\hline " & D 16 & 35.3 & 51.8 & 19. 8 \\
\hline$c-5$ & D 13 & 34.8 & 51.0 & 23.4 \\
\hline$"$ & D 16 & 41.0 & 62.2 & 17. 6 \\
\hline
\end{tabular}


表一1 実殹概要

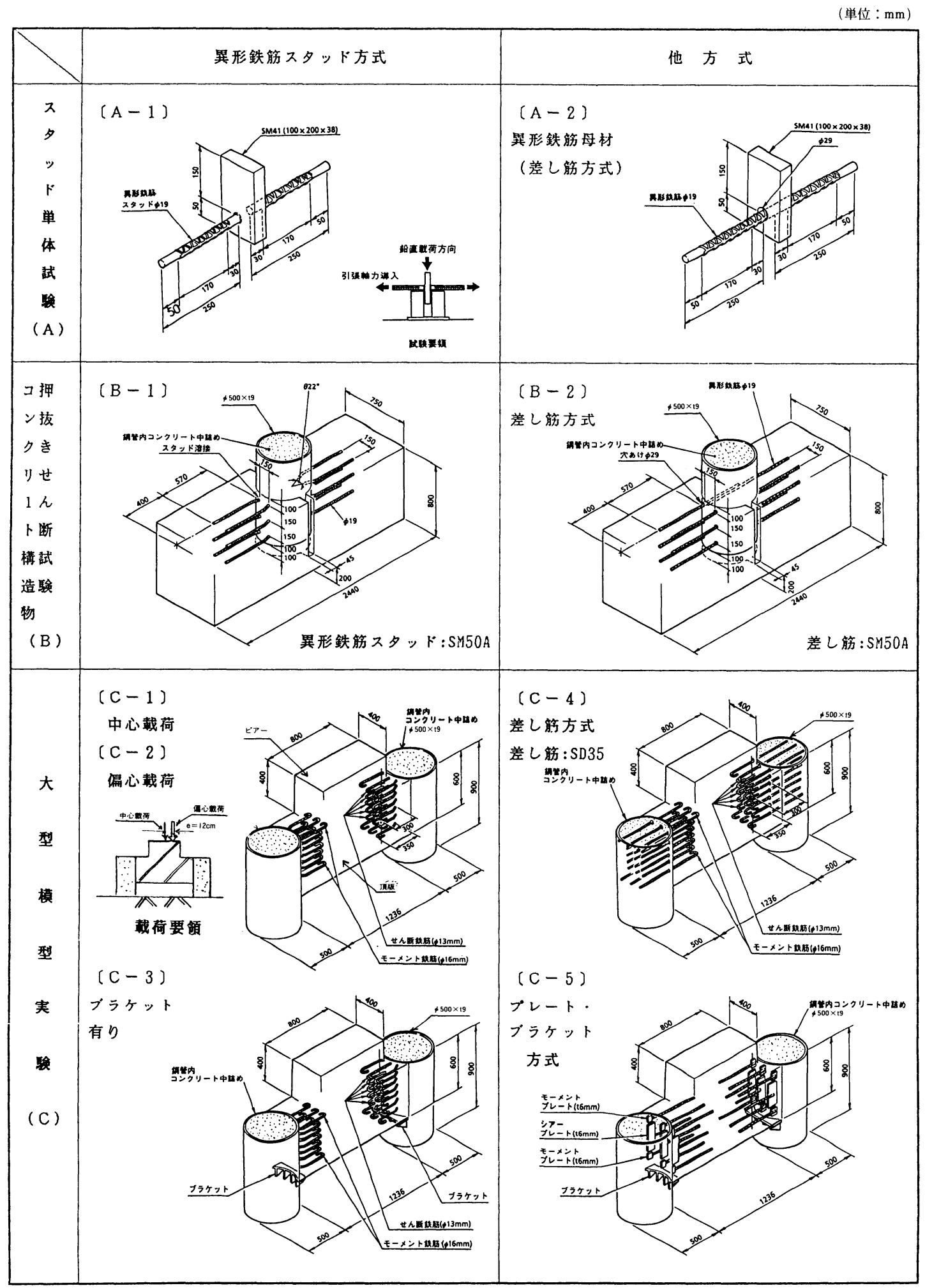


表一3 供試体コンクリートの性状

\begin{tabular}{|c|c|c|c|}
\hline 供 試 体 & $\begin{array}{c}\text { 理縮強度 } \\
\mathrm{f}_{\mathrm{c}} \\
\left(\mathrm{kgf} / \mathrm{cm}^{2}\right)\end{array}$ & $\begin{array}{c}\text { 引張強度 } \\
\mathrm{f}_{\mathrm{t}} \\
\left(\mathrm{kgf} / \mathrm{cm}^{2}\right)\end{array}$ & $\begin{array}{c}\text { スランプ } \\
(\mathrm{cm})\end{array}$ \\
\hline $\mathrm{B}-1 \sim \mathrm{B}-2$ & 248 & - & 10 \\
\hline $\mathrm{C}-1 \sim \mathrm{C}-5$ & 324 & 38.0 & 6 \\
\hline
\end{tabular}

（注）圧縮強度, 引張強度はコンクリート構造物試験時の強度で材 令 14 日の強度を示す。

表一4 異形鉄筋スタッド溶接部の機械的性質

\begin{tabular}{|c|c|c|c|c|}
\hline \multirow[t]{2}{*}{ 溶接の形状 } & \multicolumn{2}{|c|}{ 引张強さ $\left(\mathrm{kgf} / \mathrm{cm}^{2}\right)$} & \multicolumn{2}{|c|}{ 最高硬さ $\left(\mathrm{Hv}_{\mathrm{V}}(5)\right)$} \\
\hline & 試馬鈋結果 & 判定基淮 & 試哥塗吉果 & 判定基準 \\
\hline 平板上の溶接 & 50.8 & $>50$ & Max 280 & $<300$ \\
\hline 錭管上の溶接 & 50.9 & $>50$ & $\operatorname{Max} 280$ & $<300$ \\
\hline
\end{tabular}

（注）引張強さは, 平板上の溶接および鋼管上の溶接とも 10 体の平均. 硬さ試験はビッカース硬さ試験方法(JIS Z 2244) より実施した。

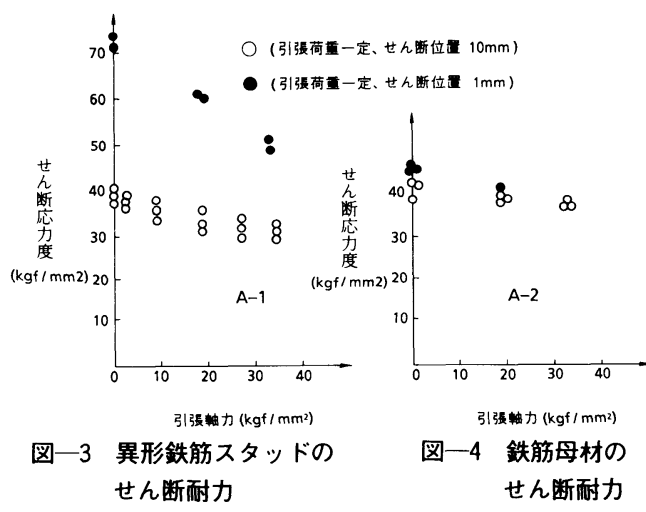

体のコンクリートの付着, 支圧強度およびせん断鉄筋の 許容応力度を原設計と同じとして耐力を推定すると, $\mathrm{C}-1 \sim \mathrm{C}-4$ は $36.5 \mathrm{tf} /$ 本, $\mathrm{C}-5$ は $36.2 \mathrm{tf} /$ 本となる. これより供試体の設計耐力に相当する載荷荷重を $30 \mathrm{tf}$ と設定した.

\section{（2）スタッド溶接単体試験}

(1)引張試験結果

試験結果を表一 4 に示す. 引張試験では, それぞれ 10 体実施したがいずれもスタッド軸部で破断し，溶接部で の破断はなく, 母材の形状 (鋼管と平板) による強度差 もなかった。 また, 曲げ試験も実施したが, 全供試体と も溶接部に久宿はみられなかった.

(2)引張せん断試験結果 (A 試験)

異形鉄筋スタッドのせん断耐力試験結果を図一3に， 比較として実施した鉄筋母材のせん断耐力試験結果を図 -4 に示す. 図一 3,4 では, せん断耐力がせん断位置に よって変化するため $1 \mathrm{~mm}, 10 \mathrm{~mm}$ の 2 ケース示した. まず, 引張軸力が作用していないと，異形鉄筋母材その もののせん断耐力は，せん断位置に関係なくほぼ41
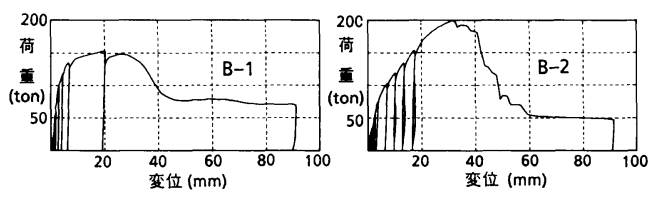

異形鉄飭スタッド式

差し筋方式
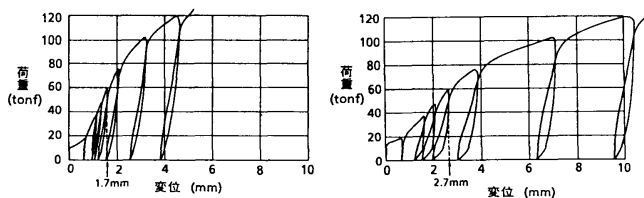

図一5 荷重 相対変位

\section{表一5 最大荷重と設計荷重との比較}

\begin{tabular}{|c|c|c|c|c|c|}
\hline 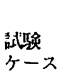 & 結合方式 & $\begin{array}{c}\text { 最大荷重 } \\
\text { (tonf) }\end{array}$ & $\begin{array}{c}\text { 一本当たり } \\
\text { の最大荷重 } \\
\text { A (tonf) }\end{array}$ & $\begin{array}{c}\text { 一本当たり } \\
\text { の設計荷重 } \\
\text { B(tonf) }\end{array}$ & 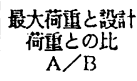 \\
\hline$B-1$ & $\begin{array}{l}\text { 異形鉄筋 } \\
\text { スタット }\end{array}$ & 155 & 12. 9 & 3. 4 & 3. 8 \\
\hline$B-2$ & 差し筋 & 199 & 16.5 & 3. 4 & 4. 8 \\
\hline
\end{tabular}

$45 \mathrm{kgf} / \mathrm{mm}^{2}$ と一定していた (図一4). 一方, 異形鉄筋 スタッドでは, せん断位置 $1 \mathrm{~mm}$ のきのせん断耐力は, せん断耐力 $10 \mathrm{~mm}$ のとの 1.85 倍と大きく, 72 $\mathrm{kgf} / \mathrm{mm}^{2}$ であった (図一3).これは，せん断位置 $1 \mathrm{~mm}$ の試験では, 余盛部も抵抗しており見掛け上大きくなっ たといえる.

次に, 異形鉄筋スタッドの場合, 引張軸力作用下での せん断耐力については, せん断位置 $10 \mathrm{~mm}$, 作用引張 軸力 $0.9 \sigma_{y}\left(\sigma_{y}\right.$ : 降伏強度）という厳しい条件下でも, 作用軸力がない場合と比較してせん断耐力の低下割合は $77 \%$ で, せん断耐力 $26.2 \sim 32.2 \mathrm{kgf} / \mathrm{mm}^{2}$ 程度あり十分 なせん断耐力を有することが確認された.

\section{（3）押し抜きせん断試験結果（B試験）}

押し抜きせん断試験の荷重〜相対変位の結果を図一5 に，最大荷重と設計荷重との比較を表一 5 に示した。異 形鉄筋スタッドの許容せん断応力度を母材の許容引張応 力度 $20 \mathrm{kgf} / \mathrm{mm}^{2}$ の $60 \%$ ，すなわち $12 \mathrm{kgf} / \mathrm{mm}^{2}$ と考え て設計すると, 試験体の常時設計荷重 $40 \mathrm{tf}$, 常時設計 荷重の 1.5 倍で $60 \mathrm{tf}$ となる. 図一5で, 載荷荷重 $60 \mathrm{tf}$ においてスタッド方式では鋼管とコンクリートとの相対 変位が $1.7 \mathrm{~mm}$ であり, 一方, 差し筋方式では $2.7 \mathrm{~mm}$ であったことから，スタッド方式は設計耐力レベルでは より剛な結合形式であるといえる.

また，異形鉄筋スタッド方式の最大耐力は常時設計荷 重の約 4 倍であることが確認できた。このときの異形鉄 筋スタッドの最大せん断応力度は一本当たり 39 $\mathrm{kgf} / \mathrm{mm}^{2}$ であり, 前項引張せん断耐力試験で得た結果 (図一3,10 $\mathrm{mm}$ のケース, 導入軸力がない場合) と同 
表一6 実験結果一筧表

\begin{tabular}{|c|c|c|c|c|c|c|c|c|c|c|c|c|}
\hline \multirow[b]{2}{*}{ 結合方式 } & \multirow[b]{2}{*}{ 結合部材 } & \multicolumn{3}{|c|}{ ひひ割れれ発生何重（Lonf） } & \multicolumn{4}{|c|}{ 戎荷㑸望 90 tonf ての } & \multirow[b]{2}{*}{$\begin{array}{c}\text { 最大荷重 } \\
\text { (tonf) }\end{array}$} & \multirow[b]{2}{*}{ 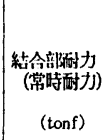 } & \multirow{2}{*}{ 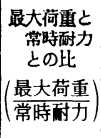 } & \multirow[b]{2}{*}{ 破婊形態 } \\
\hline & & 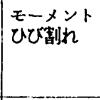 & $\begin{array}{l}\text { せん断 } \\
\text { ひひ揢ん }\end{array}$ & 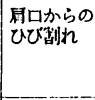 & 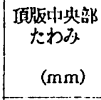 & 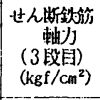 & 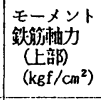 & 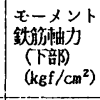 & & & & \\
\hline$c-1$ & 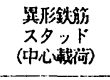 & 50 & 135 & 100 & 1. 54 & 485 & 13 & 257 & 183 & 36.5 & 5. 0 & 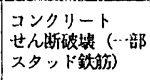 \\
\hline$c-2$ & 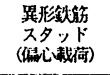 & 40 & 125 & 65 & 1. 50 & 564 & 35 & 161 & 173 & 36.5 & 4. 7 & 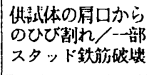 \\
\hline$c-3$ & 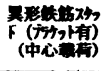 & 45 & 160 & 260 & 1. 35 & 313 & -65 & 217 & 332 & 36.5 & 9. 0 & $\begin{array}{c}\text { コンクリート } \\
\text { 壬丧 }\end{array}$ \\
\hline$c-4$ & 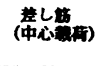 & 55 & 130 & 60 & 2. 11 & 603 & -434 & 1449 & 173 & 36.5 & 4. 7 & $\begin{array}{l}\text { 供試体の周口 } \\
\text { からのひひ㓤れ }\end{array}$ \\
\hline$C-5$ & 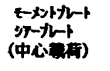 & 75 & 125 & 100 & 1. 45 & 32 & -271 & 188 & 278 & 36.2 & 7. 6 & $\begin{array}{l}\text { コンリリート } \\
\text { 正壊 }\end{array}$ \\
\hline
\end{tabular}

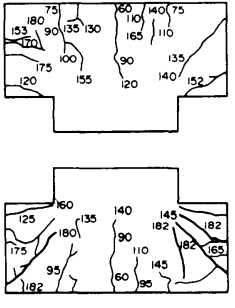

貲形鉄施スタッド式(C-1)
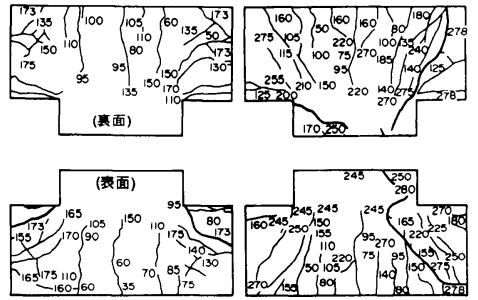

能方式(C-4)

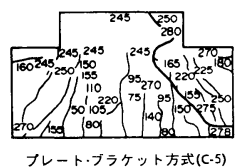

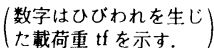

図一 6 ひびわれ発生状況

様であった。

\section{（4）大型模型実験結果}

実験仕様は昭和 61 年度に阪神高速道路公団で実施し た差し筋方式模型実験 ${ }^{3)}$ と同一とした.

a) 最大荷重と破壊過程

各供試体での最大荷重とその破壊過程での状況を整理 すると表一 6 のようになる. 最大荷重と設計荷重との比 較では，スタッド方式，差し筋方式はほぼ同じ値であっ たが，プレート・ブラケット方式は，これらより約 1.5 倍の値であった.

b) 3 方式の比較

(1) ひびわれ発生と破壊状況

ひびわれ発生状況としては，50７0 tf でモ一メント による曲げひびわれが共通して発生している．さらに荷 重が増加すると, 図一6（表一1に示す供試体を展開し た形で示している) で示しているようにプレート・ブラ ケット方式ではブラケット先端より斜め方向に入ったひ びわれがピアー部に至り, 差し筋方式では頂版肩口から 発生し 10 度の方向に鋼管に至る.そして, 異形鉄筋ス タッド方式では鋼管と異形鉄筋スタッドとの接合部より 45 度斜め方向に最大荷重時に特徴的なひびわれが生じ

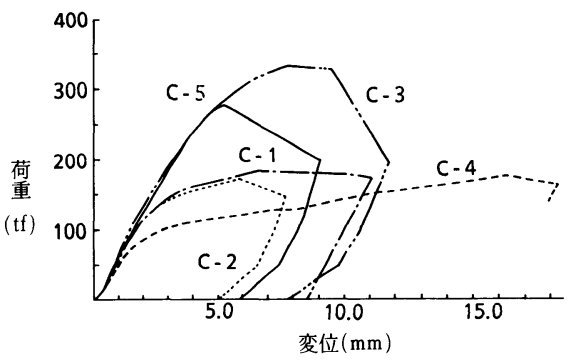

図一7 各結合形式における荷重-变位関係

た。

(2) 荷重-変位関係

図一7には，各結合方式における荷重-変位関係（変 位は頂版下面中央部での測定值）が示されている．いず れの方式においても，荷重レベルが $60 \mathrm{tf}$ 程度までは頂 版内のプレート，鋼管または鉄筋とコンクリートとの付 着で荷重を受け持っていると考えられ，線形的な動きを 示している.さらに荷重が増加していくと，図一7およ びブラケット，結合鉄筋に発生するひずみから判断して ひびわれの発生時点から荷重分担機構が変化し, プレー ト・ブラケット方式ではブラケットが荷重分担してい き,さらに線形的な関係を続けていくが, 他の 2 方式で は結合鉄筋のせん断ずれ変形が大きくなり, 非線形関係 を示した。

(3) 結合部における応力状態

今回実験したせん断力が卓越するモデルでは図一8よ りプレート・ブラケット方式と差し筋方式とで軸力の大 きさは差があるものの, 三角形分布でその分布形状はよ く似ている. 一方異形鉄筋スタッド方式は他の 2 方式と 比較してすべての段のせん断鉄筋位置において引張力が 発生しており,かつ分布形状も放物線分布となっており, 他方式よりは均等に作用している. 


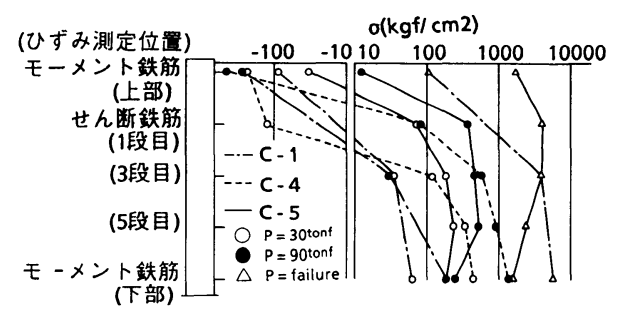

(発生応力は絶対値を対数評価した)

\section{図一8 結合部の応力状態}

しかし，荷重に対する結合鉄筋の応力からみると，90 tf ではプレート・ブラケット方式や異形鉄筋スタッド方 式が, $200 \sim 500 \mathrm{kgf} / \mathrm{cm}^{2}$ 程度であるのに対して, 差し 筋方式では $500 〜 1500 \mathrm{kgf} / \mathrm{cm}^{2}$ 程度となっており，結 合部における応力状態はそれぞれの結合方式の特色が示 された。また作用せん断応力度（載荷荷重を結合鉄筋の 純断面積 $A_{s}=61.8 \mathrm{~cm}^{2}$ で除した值）と結合鉄筋に発生 した引張応力度との関係に着目すると, $90 \mathrm{tf}$ まで, 発 生する引張応力度は作用せん断応力度と線形関係にあ り，かつ，絶対值は下回り，スタッド方式では 26〜37\%， 差し筋方式では 27〜 67\% であった.

c）異形鉄筋スタッド偏心載荷試験結果

偏心量は，頂版上面に鉛直力の 2 割の水平力が作用し たときに，頂版下面に発生するモーメントが同じになる ように中心線より $12 \mathrm{~cm}$ とした.

(1)ひびわれ発生と破壊状況

両方の載荷位置での試験とも曲げひびわれ， せん断ひ びわれが，それぞれ 40〜 50 tf，125〜135 tf と同様な載 荷重で発生している. しかし，中心載荷では顥著でない 頂版天端肩口からのひびわれが，偏心載荷では偏心側に 発生している．また，破壊状況をみると，中心載荷では 頂版下面と鋼管との接合部より 45 度方向に進展してい く斜めひびわれが荷重増加とともに進展していくのに対 し, 偏心載荷では肩口からのひびわれが顥著に進展し両 者のひびわれ発生は異なった.

(2) 荷重-変位関係

頂版下面の変位状況を図一9に示す. 頂版中央部変位 でみると, $150 \mathrm{tf}$ までは載荷位置の差による挙動の差は ほぼない. しかし, その後の載荷により両者の挙動に大 きな差が生じた。

(3) 結合部における応力状態

図一10に結合部鉄筋の発生応力を示すが, 設計荷重 の 3 倍の $90 \mathrm{tf}$ では中心載荷, 偏心載荷とも変位 (図一9) や結合部鉄筋の発生応力には差がみられない.このこと よりせん断力が卓越する形式では, 設計において偏心載 荷状況を想定して結合部鉄筋の発生応力の割増しをする 必要はなく, 現設計手法で問題ないといえる.しかし, 載荷重が増していくと, 偏心載荷では偏心載荷側の鉄筋

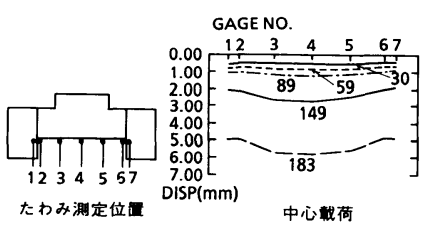

図一9 頂版下面の変位状況（荷重単位：tf）

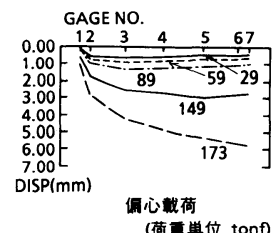

(荷直单位 tonf)

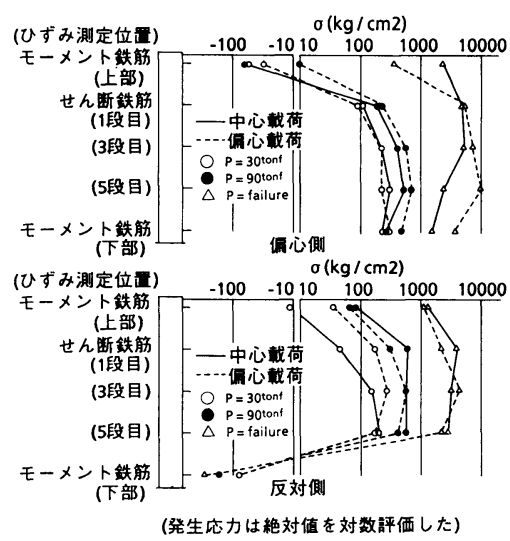

図一10 結合部における応力状態 [中心載荷 (C-1), 偏心載荷 $(\mathrm{C}-2)]$
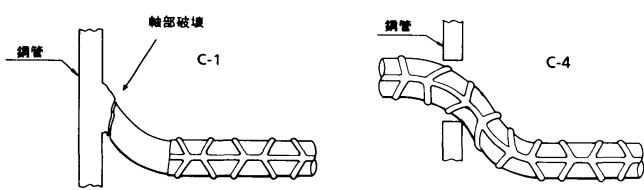

図一11最大変位時の結合部の状況

応力は反対側の約 2 倍の応力が発生しており, 上記(1)項 で示したコンクリートの破壊形態の差等, 限界状態設計 法では，両者の差を考慮する必要がある.

d）最大変位時の結合部の状況

破壊後各供試体のコンクリートを慎重にはつり，結合 部の状況を調査した。その結果，

(1) プレート・ブラケット方式では，最大荷重におい てもプレートは十分に余裕を有していると推定される が，ブラケットは鋼管との結合部付近で座屈していた。

(2) 差し筋方式では，差し筋そのものは鋼管挿入穴で 大きく変形し，かつ，断面が減少しているが，破断まで には至っていない.

(3) 異形スタッド方式では, 最大変位時でスタッドが 一部破断していた。この破断箇所は，スタッドの発生軸 力の大きい箇所と一致していた.

これらの破壊状況を図一11に示す.

e) じん性率

載荷荷重 $P$ と頂版中央部変位 $\delta$ との関係からじん性 率を計算すると，表一7のようになる，じん性率の算定 
表一7 各供試体のじん性率

\begin{tabular}{|c|c|c|c|c|c|c|c|}
\hline \multirow[b]{2}{*}{$\begin{array}{c}\text { 供武体 } \\
\text { No }\end{array}$} & \multicolumn{3}{|c|}{ 降 伏 時 } & \multirow{2}{*}{ 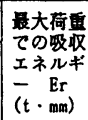 } & \multirow{2}{*}{ 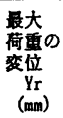 } & \multicolumn{2}{|c|}{ ヒん性率 } \\
\hline & $\begin{array}{l}\text { 霝 重 } \\
\text { (tonf) }\end{array}$ & $\begin{array}{l}\text { 吸収工ネ } \\
\sim \neq-E y \\
(t \cdot \mathrm{mm})\end{array}$ & $\begin{array}{c}\text { 变 } \\
(\mathrm{yy} \\
(\mathrm{mm})\end{array}$ & & & $\mathrm{Er} / \mathrm{Ey}$ & $\begin{array}{l}\mathrm{Yr} / \mathrm{Yy} \\
\text { 塑性率 }\end{array}$ \\
\hline$c-1$ & 130 & 172 & 2.5 & 882 & 6.9 & 5.1 & 2.8 \\
\hline$c-2$ & 130 & 150 & 2.4 & 684 & 5.8 & 4.5 & 2.4 \\
\hline$c-3$ & 200 & 328 & 3.2 & 1,671 & 8.0 & 5.1 & 2.5 \\
\hline$c-4$ & 100 & 176 & 2.9 & 1,494 & 11.4 & 8.5 & 3.9 \\
\hline$c-5$ & 180 & 270 & 3.0 & 797 & 5.3 & 3.0 & 1.8 \\
\hline
\end{tabular}

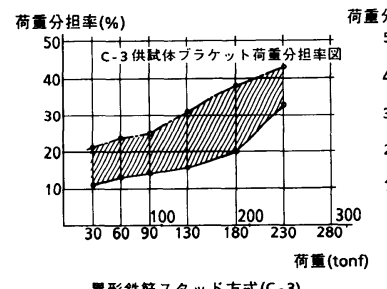

翼形錐䏦スタッド方式(C-3) 図一12 ブラケットの荷重分担率

に用いた降伏荷重の判定は, $\log P \sim \log \delta$ 関係の急変 部より判定した. また, じん性率の評価は吸収エネルギー と変形性能との下記の 2 通りの考え方により行った.

・吸収エネルギーによる評価

$\nu_{E r}=\frac{E_{r}}{E_{y}}=\frac{\text { 最大荷重での吸収エネルギ一 }}{\text { 降伏荷重での吸収エネルギ一 }}$

・変形性能による評価

$\nu_{r}=\frac{Y_{r}}{Y_{y}}=\frac{\text { 最大荷重での変位 }}{\text { 降伏荷重での変位 }}$

f）ブラケットの荷重分担率

プレート・ブラケット方式 (C-5) と異形鉄筋スタッ ド方式 (C-3) について, ブラケットのひずみより推定 したブラケットの分担率を図一12に示す. 分担率の幅 の推定にあたっては,模型実験でのブラケットのひずみ, およびブラケットのみの載荷試験でのひずみ測定を行っ $た^{3)}$. ブラケットのみの載荷試験は, 模型実験でのブラ ケット上部のコンクリートの支圧分布形態を数種類仮定 して実施した。ブラケットのみの載荷試験のひずみと模 型実験でのひずみを比較し，ブラケットに最大ひずみお よび最小ひずみを生じさせる荷重形態を推定し，分担率 の幅とした，設計荷重（30 tf）では，C-5 は，10\% 程 度以下であり, その後 $180 \mathrm{tf} て ゙ 17 〜 30 \%$ となっている. 一方, C-3 の分担率は設計荷重 (30 tf) では, C-5 の 2 倍とプレートとスタッドとの剛性差を示しているが, 載 荷荷重を増加するに伴いブラケットの分担が大きくな

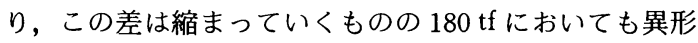
鉄筋スタッド方式が約 1.5 倍, ブラケットの分担率は大 きい.

以上, 現在の結合部設計では, 最大荷重と設計荷重と
の比較 (表一5参照) 等合わせて考えると, ブラケット の剛性を若干落とし得るものの, プレート・ブラケット 方式をとる以上，ブラケットを省略することは不可と考 えられる.

\section{（5）異形鉄筋スタッド方式の評価}

以上の実験検討の結果，異形鉄筋スタッド方式の結合 エについて以下のことを明らかにした。

1）試験体 B-1，C-1 の最大荷重での設計耐力に対 する比は $3.8,5.0$ 倍であり, 差し筋方式とほぼ同等で ある.

2）降伏時まで，頂版中央部における変位は異形鉄筋 スタッドの方が差し筋方式に比べて約 7 割と小さい.

3）降伏時（変位量で 2 3 mm) での吸収エネルギー でみると，異形鉄筋スタッド方式と差し筋方式ではほぼ 同等である。

4）異形鉄筋スタッド方式では，配置した各段のせん 断鉄筋の発生軸力がほぼ均等である。

5）せん断鉄筋に作用する引張軸力は, 設計荷重の 3 倍でも $570 \mathrm{kgf} / \mathrm{cm}^{2}$ 以下であり, 引張軸力が作用した場 合でのせん断耐力の低下を設計に考慮する必要はない.

6) 偏心載荷試験も，設計耐力レベルにおいて中心載 荷試験と同様な発生応力, 頂版変位を示しており, 許容 応力度設計手法としては, 現行の設計手法を用いてもよ いといえる.

\section{（6）異形鉄筋スタッド方式の設計方法の提案}

異形鉄筋スタッド方式頂版結合工の実設計において必 要なせん断耐力の設計法について提案する.

(1) 許容せん断応力度

表一8に各種試験結果をとりまとめ, 許容せん断応力 度を検討した。 まず，降伏荷重時のせん断応力度に対し て, SD 35 異形鉄筋の引張強度での安全率 1.75 (= $3500 \mathrm{kgf} / \mathrm{cm}^{2} \div 2000 \mathrm{kgf} / \mathrm{cm}^{2}$ ) を，各種試験結果に適 用すると異形鉄筋スタッド単体では $1657 \mathrm{kgf} / \mathrm{cm}^{2}$ とな り，また，押し抜きせん断試験，大型模型実験結果から は $1201 〜 1661 \mathrm{kgf} / \mathrm{cm}^{2}$ となる.

さらに破壊荷重時の値についても同様に計算すると, $\mathrm{SD} 35$ の安全率 $2.5\left(5000 \mathrm{kgf} / \mathrm{cm}^{2} \div 2000 \mathrm{kgf} / \mathrm{cm}^{2}\right)$ よ

表一8 各種試験によるせん断強度

\begin{tabular}{|c|c|c|c|c|}
\hline \multirow[b]{2}{*}{ 武翼項目 } & \multicolumn{2}{|c|}{ 武 結 果 } & \multicolumn{2}{|c|}{ 许容応力度の没定 } \\
\hline & $\begin{array}{c}\text { 隆伏荷重時の } \\
\text { せん断虑力度 } \\
\text { P y }\end{array}$ & 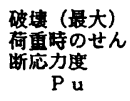 & $\frac{P y}{1.75}$ & $\frac{P u}{2.5}$ \\
\hline スタッド単体式楼 & 2900 & 3900 & 1657 & 1560 \\
\hline 押拔せん断試验 & 2908 & 4508 & 1661 & 1803 \\
\hline 槙型実輩（中心戎荷） & 2103 & 2961 & 1201 & 1184 \\
\hline 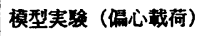 & 2103 & 2799 & 1201 & 1119 \\
\hline
\end{tabular}

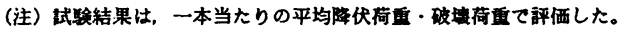


り，異形鉄筋スタッド単体では $1560 \mathrm{kgf} / \mathrm{cm}^{2}$ ，またコ ンクリート構造物としては $1119 \sim 1803 \mathrm{kgf} / \mathrm{cm}^{2}$ とな る.

ここで，最小值を示している模型実験（偏心載荷）の 最大荷重での破壊形態が, 頂版コンクリートのせん断ひ びわれによるもので，せん断鉄筋の破壊でないため参考 値とし, 許容応力度としては $1200 \mathrm{kgf} / \mathrm{cm}^{2}$ とした。

(2) ずれ止め耐力式との比較

「道路橋示方書 II 鋼橋編（日本道路協会）」によれば, 頭付スタッドのずれ止め耐力はコンクリート強度と $H / d$ の関数であり次式で与えられる.

$$
Q_{a}=\alpha d^{2} \sqrt{\sigma_{c k}}
$$

ここに, $Q_{a}:$ ずれ止めのせん断耐力 $\left(\mathrm{kgf} / \mathrm{cm}^{2}\right)$

$$
d: \text { スタッドの軸径 }(\mathrm{cm})
$$

$\sigma_{c k}:$ 設計基準強度 $\left(\mathrm{kgf} / \mathrm{cm}^{2}\right)$

$$
H \text { : スタッドの高さ (長さ) }(\mathrm{cm})
$$

異形鉄筋スタッドのせん断耐力に, 上記で設定した許 容せん断応力度 $1200 \mathrm{kgf} / \mathrm{cm}^{2}$ を用い，また $\sigma_{c k}=240$ $\mathrm{kgf} / \mathrm{cm}^{2}$ として式（1）を適用すると， $\alpha=61$ となる. 同示方書において， $\alpha=30$ ( $H / d>5$ のとき) となって おり，異形鉄筋スタッドのせん断耐力は，ずれ止めのせ ん断耐力の約 2.1 倍を採用することとなる。これは, 同 示方書でのせん断耐力の設定が, 自動車の繰り返し荷重 を対象とし, 安全率を降伏に対して 3 以上, 破壊に対し て 6 以上としているが, 頂版結合部は, 死荷重または地 震時の荷重が支配的であり, 今回設定した許容せん断応 力度で十分安全であると考える.

\section{4. 施工に関する研究}

\section{（1） $\phi 19 \mathrm{~mm} \cdot$ 水平・長尺スタッド溶接の開発}

太径鉄筋の水平スタッド溶接には，溶接時の溶融金属 のたれの処置が最大の問題であり, 従来スタッド径とし ては品質保証できる最大径は $16 \mathrm{~mm}$ までであった。こ れについて, 駆動源としてエアーシリンダーを用い, 溶 接ガンに十分な駆動力と制御性をもたせることにより， $19 \mathrm{~mm}$ を可能とした.

一方, 高強度に伴う溶接性の問題点は, 鉄筋は一般に 溶接に適した材質ではないため, 使用鋼材は溶接性の良 いものとし，その規格は，溶接構造用圧延鋼材 SM 50 A (JIS G 3106) とした. 異形鉄筋スタッドの化学成分 および機械的性質を表一9に示す.

今回開発したスタッドガンの機構図を図一13に示す. この, 新開発ガンを用いて, 従来タイプのハンディガン との溶接比較試験を行った結果を図一14に示す.

従来のハンディガンは下向き姿勢では広い溶接適性範 囲を示したが, 水平姿勢では適性範囲は狭く, しかもこ の水平姿勢での適性範囲内でも 30 本の溶接試験を行う

\begin{tabular}{|c|c|c|c|c|c|c|}
\hline $\mathrm{C}$ & $\mathrm{Si}$ & $\mathrm{Mn}$ & \multicolumn{2}{|l|}{$P$} & \multicolumn{2}{|c|}{$\mathrm{s}$} \\
\hline 0.20以下 & 0.55 以下 & 1.50以下 & \multicolumn{2}{|c|}{0.04 以下 } & \multicolumn{2}{|c|}{0.04 以下 } \\
\hline \multicolumn{7}{|c|}{ (機栈的性劦) } \\
\hline $\begin{array}{l}\text { 降伏点 } \\
\text { 又は耐力 } \\
\left(\mathrm{kgf} / \mathrm{mm}^{2}\right)\end{array}$ & $\begin{array}{l}\text { 引張強さ } \\
\left(\mathrm{kgf} / \mathrm{mm}^{2}\right)\end{array}$ & 武験片 & $\begin{array}{r}\text { 伸び } \\
(\%)\end{array}$ & 曲け & 争度 & 曲げ直径 \\
\hline 35 以上 & $50 \sim 62$ & 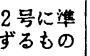 & 18 以上 & 180 & 度 & $\begin{array}{l}\text { 公称直径 } \\
\text { 倍 }\end{array}$ \\
\hline
\end{tabular}

表一9 異形鉄筋スタッドの化学成分および機械的性質 [化学成分]
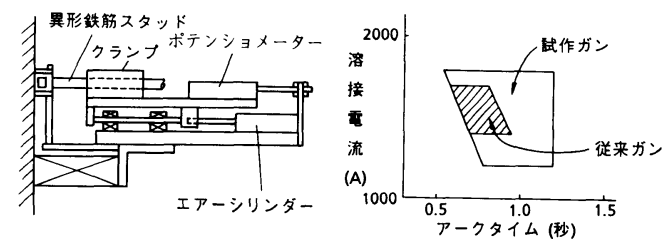

図一13 試作スタッドガンの機構 図一14 適正溶接条件範囲

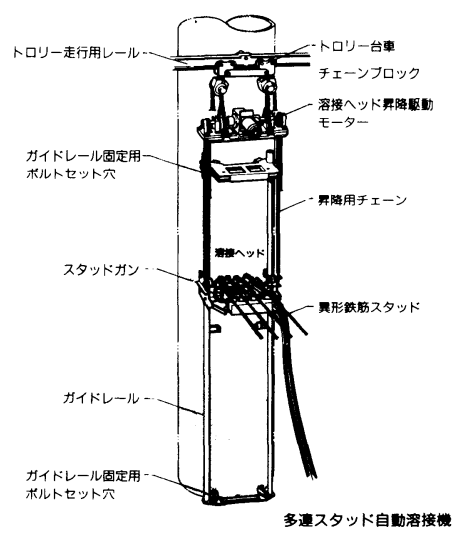

図一15多連スタッド自動溶接機

と $30 \%$ もの不良溶接が発生した。一方，今回開発した スタッドガンは, 水平姿勢でも従来ガンでの下向き溶接 条件とほぼ同条件で不良率 $0 \%$ で全本数実施すること ができた.

\section{（2）多連スタッド自動溶接機}

異形鉄筋スタッド方式頂版結合工においては，鋼管矢 板一本当たり 100 本以上の異形鉄筋スタッドを打設する 必要がある.このため, 施工の確実性, 信頼性と施工能 率の向上を図るため, 水平方向に異形鉄筋スタッドを自 動溶接できる多連スタッド自動溶接機を開発した.

多連スタッド自動溶接機とは, 図一15に示すように, 水平方向に異形鉄筋スタッドを所定本数自動溶接でき, また上下方向に溶接ヘッドを自動昇降できる溶接機で, エアーシリンダー方式によるスタッドガンを必要台数配 置した溶接ヘッド, 昇降駆動装置, ガイドレールおよび トロリー台車から構成される. 施工状況を写真一1に示 す. 


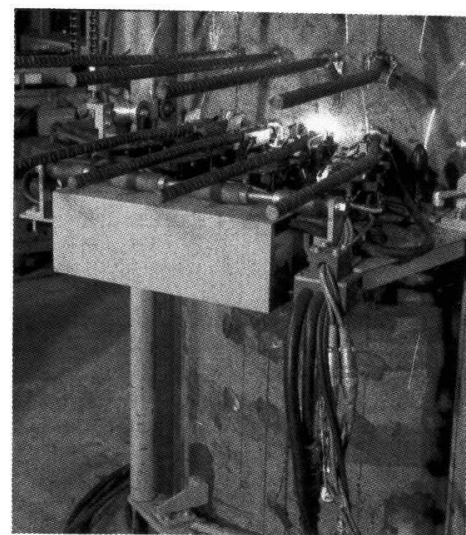

写真一1 多連スタッド自動溶接機による溶接状況

表一10 溶接適性範囲

\begin{tabular}{|c|c|c|c|}
\hline \multicolumn{2}{|c|}{ 溶接条件項目 } & 下 限 & 上 限 \\
\hline 溶接電流 & (A) & 1400 & 1800 \\
\hline 溶接時間 & (sec) & 0.7 & 1. 1 \\
\hline スタッド弓 & (mm) & 2. 0 & 4. 0 \\
\hline スタッド批 & (mm) & 4. 0 & 8. 0 \\
\hline
\end{tabular}
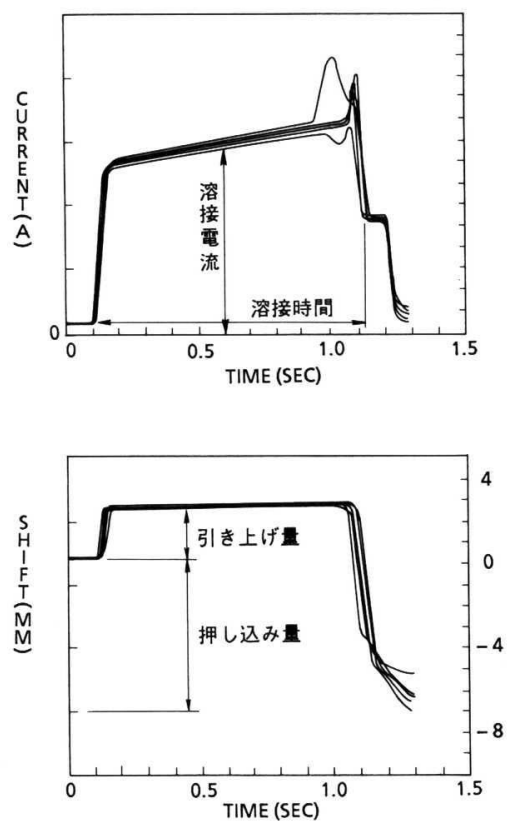

図一16 モニター画面例（5 回繰り返し試験結果）

\section{（３）スタッド溶接の品質管理装置}

従来スタッド溶接の品質管理は, スタッド溶接部の目 視検査と抜き取りによる打撃曲げ武験が行われてきた. 本結合工では多本数自動化溶接に対しての品質管理を高 めるため，モニタリング装置を開発した.

すなわち, 各溶接ごとに必要な溶接条件一溶接電流・
アーク時間・スタッドの移動量（引き上げ量・押し込み 量)一をモニターすることにより, 現場において非破壊 で溶接品質を管理することとした。

このモニタリング装置を用いる場合の $\phi 19 \mathrm{~mm} \cdot$ 水 平・異形鉄筋スタッド溶接の溶接適性範囲を表一10 に, モニター画面例を図一16 に示す. 図一16 に示す 5 回繰 り返し試験結果より, 同一の溶接条件設定での溶接現象 （溶接電流・スタッドの引き上げ量・押し込み量）の安 定度が確保されているのがわかる.

\section{5. あとがき}

異形鉄筋スタッド方式による鋼管矢板基礎の頂版結合 工について, 現在使用されているプレート・ブラケット 方式, 差し筋方式を含めた性状確認試験を進めてきた。 その結果,

（1）いずれの方式も通常考えられている設計での安 全性は十分確保されている. 特にプレート・ブラケット 方式は最大荷重, 降伏荷重について安全率が大きい.

（2）差し筋方式と異形鉄筋スタッド方式は，ほぼ同 じような安全性を有している，また差し込み鉄筋とス タッド鉄筋との機能性が顕著な差として表われている. すなわち差し込み鉄筋はきわめて大きな変形を取り得 る.しかし，スタッド鉄筋は変形性能が小さいため，せ ん断剛性が大きくかつ均等にせん断力が分布することが わかった。

（３）従来実施されなかった地震時水平力作用を想定 した偏心載荷試験を実施したが, 設計荷重の 3 倍レベル までは，中心載荷試験結果と同様な挙動を示したことに より，水平力が作用する場合も従来の設計手法を適用し ても問題ないといえよう.

なお，本検討でのモデルはせん断の卓越したケースで あるが，頂版のスパンの長い曲げタイプに対してはこれ までの検討結果からプレート・ブラケット方式, 差し筋 方式では頂版結合部での破壊が生じないことが確認され ている4),5).このことから異形スタッド方式でも破壊形 状には変化がないと思われる.

今後は, 予定されている実橋試験施工により実施工上 の工夫を行い本工法を完成させていく必要がある．また 本工法の適用範囲を拡大するには, 直径 $22 \mathrm{~mm}$ の太径 異形鉄筋の水平打ちの実用化が必要之考えられる.

本工法は, 鋼管矢板基礎にとどまらず，今後建設が増 大しつつある地下空間やウォーター・フロントでの建設 工事の鋼製部材 (鋼管矢板, 鋼矢板等) とコンクリート との合成構造に適用されていくものと思われる.このた め, 今後スタッドの径, 長さ, 打設ピッチやコンクリー 卜強度等をパラメーターとした基礎実験を行い, これら 合成構造についての新しい設計要領を提案していきた 
い.

最後に,本検討の実施にあたってご指導して頂いた「異 形鉄筋スタッド方式頂版結合工研究会」の藤井 学（主 査 ; 京都大学), 小柳教授 (岐阜大学), 小林助教授 (京 都大学) ならびに各委員に深甚なる謝意を表します。

$$
\text { 参 考 文 献 }
$$

1）「鋼管矢板基礎設計指針・同解説」，日本道路協会， 1984 .
2）「道路橋示方書・同解説IV下部構造編」, 日本道路協会, 1980.

3）「鋼管矢板基礎頂版結合部の模型実験解析業務報告書」, 阪神高速道路公団・新日本製鐵（株），1988.

4）「矢板式基礎頂版結合部の模型実験報告書」, 阪神高速道 路公団・鋼管杭協会, 1977.

5）「鋼管矢板基礎頂版結合部の模型実験報告書」, 阪神高速 道路公団・鋼管杭協会, 1986 .

（1988.12.6 • 受付） 